\title{
Women's/ Gender Studies: Missing Link to Restructure Social Institutions
}

\author{
Astha Priyadarshini \\ Department of Gender Studies, Rajiv Gandhi National Institute of Youth Development, India
}

Copyright $\mathrm{C} 2018$ by authors, all rights reserved. Authors agree that this article remains permanently open access under the terms of the Creative Commons Attribution License 4.0 International License

\begin{abstract}
Women's Studies as a discipline, has helped in producing knowledge from the perspective of women. The worldview developed by women has gained much interest in India today. This is due to the continuous efforts of women producing knowledge in every field be it arts, science or technology. But the visibility of women and Women's Studies is still a pertinent question asked in the universities teaching women's/ gender studies. Feminists have made several attempts to challenge the patriarchal institutions. Both scholars and activists have tried to break this chain of hierarchical structure. Feminist epistemologies and methodology have also been limited to scholars in Women's Studies. As pointed out by many research scholars, the NGO-isation of the discipline has contributed to this limitation. This marginality in university settings has restricted Women's Studies from becoming the tool it had initially intended to be. The teachings and understandings have also evolved from personal to political and now to individual level. Therefore, as a student of gender studies, one is informed of both the women's movements and Women's Studies. But the experience also tells that the larger part of the society is unaware of these struggles. Also, very essential is to note that one was not aware of both movement and discipline before beginning as a learner of this discipline. This paper is an attempt to underline the marginal preference shown towards Women's Studies by other institutions like universities which have led to limited reach of Women's Studies to NGOs and few other institutions. Policy making and implementation bodies have long been gender insensitive. Educational institutions also need gender sensitive individuals for analyzing and structuring course materials that are apt for a gender aware new generation. Such institutions can potentially answer the question of employability and training of Women's Studies practitioners.
\end{abstract}

Keywords Scope of Women's/Gender Studies, Women's Movement, Employability, Bridging Institutions, Autonomy, Assimilatory Pedagogy
This paper is my quest into Gender Studies which has led me to explore the tremendous possibilities (and a few limitations) that this discipline has upheld to my generation of learners. My generation came four decades after India's independence from British and as the democratic republic which India was declared as, I got to enjoy so many things without having to fight for it. And certainly, there's still more to achieve. As a female-born person in semi-urban middle class family in India, I can say that I also have had my own struggles along with those privileges. I also had the 'privilege' of being born in a General Caste category family with both parents graduate in a state with one of the lowest literacy rate in India. While I continue to negotiate about how I want to spend my life, I didn't have to for education or my right to employment like many others in my generation also have to do. And certainly, I was extremely 'lucky' to get an exposure to Women's/ Gender Studies in my early twenties, as it has proved to be very life-changing for me in various respects. It tells me that I owe much of my privileges to Women's Movements across the world.

Thus, in this paper using this self -reflexivity and my position as a learner of Gender Studies in India I have attempted to reflect on some aspects that Gender/ Women's Studies is of tremendous concern today. I begin by analyzing how Women's Studies took shape in India, its present status and its linkages to the Women's Movement. Then I move on to explore how social institutions can be restructured for including feminist perspectives.

\section{History of Women's Studies in India and its Ever Changing Status}

In India, Women's Movement has led the way towards Women's Studies. Women's struggle is as old as it is new. Women's Movement has traversed a long struggle which began much like the Freedom Struggle in India. A large number of Indian Women still continue to struggle for their fundamental rights. Women's organizations, NGOs 
working for women empowerment and various other pressure groups continue to participate in Women's efforts to achieve justice for the female born sex, both individually and in solidarity. Yet there remains a need to decolonize India of its rudimentary systems of dowry violence, female feticide, caste oppression, colour and work-place discrimination, etc. among other such gender biases.

But still the progress is such that once it was only a demand for education, to now feminism being debated as the critical standpoint of this very education for women. This journey from being an object to the subject of study has shaped what we now know as Gender/ Women's Studies.

The first National Conference on Women's Studies held in 1981 placed Women's s Studies as a 'critical perspective' and an intellectual 'pursuit' to understand the social reality. Its separation as a program or discipline was not decided then. Instead, the recommendation was to integrate 'women's question' in all disciplines. UNESCO conference on Women's Studies in South and South-east Asia held in 1983, described it as 'critical instrument for social science development', and also a 'critical understanding of social reality'.

In India, as the first women's studies centre was established in 1974 at the SNDT Women's University in Bombay, it became the Research Centre for Women's Studies (henceforth, referred to as RCWS). With a focus on the systematic documentation of various aspects of women's lives, it could make 'data on the status of women in diverse fields' available. Premier institutions like Institute of Social Studies Trust (founded in 1976) and the Centre for Women's Development Studies (CWDS, established in 1980) also began new researches on women in the context of socio-economic and political transformation around that time.

Then, a need was felt to integrate women's studies into existing academic disciplines as courses and as a research agenda with an interdisciplinary focus. Indian Association for Women's Studies (henceforth, referred to as IAWS) and the University Grants Commission (UGC), for the first time joined for a seminar in 1985 where discussions followed for founding of separate Centres for Women's Studies within higher education institutions, to carry out research and teaching focused on women. These Centres were supposed to be "independent and parallel to the department and faculties" in order to avoid "structural constraints and delays" in coordinating research and teaching. (Swaminathan, 2006).

Women's Studies in India were propelled by an interest in equity and justice. It drew inspiration from grass-roots level experience of women's organizations. (Jain et al, 2003). These grassroots' organizations have played a very crucial role in mobilizing and organizing women to demand rights. It is also necessary to mention here that the NGO framework of women's movement has always tried to negotiate the rights of women from the governments.
Apart from consciousness raising these NGOs also played very key role in acting as pressure groups to demand policy changes from the government.

The establishment of Women's Studies centres was also a crucial phase that Women's Studies as discipline today have successfully crossed. A review of the case studies of different types of Centres in the book Narratives from the Women's Studies Family(2003), edited by Devaki Jain and Pam Rajput informs one of the struggles of these Women's Studies Centers (WSCs). It explains how these centres have faced academic isolation in the university settings, how they negotiated with it and how they addressed the needs of the community through outreach programs undertaken by them. It also talks about the role it played in shaping the personal lives of women associated with these centres. The cases in this edited narrative show how women's personal life is also integral to the development of these Women's Studies Centers. Women's Studies face a similar challenge today at most of the Indian universities. Due to its status as non-autonomous body and being headed by women Directors at most of these centers, the status of Women's Studies has just reduced to a marginal discipline in many universities where they exist as most of the higher posts in universities are also occupied by men. Though this has not deterred the strength and capacity of the women who are associated with those WSCs, but it has contributed to its stunted development as a discipline.

Sreenivas (2015) has highlighted that the 'professionalization' of the discipline has put pressures on Women's/ Gender Studies to 'be more like the other social science disciplines'. As Women's Studies emerged as a critique of other disciplines, it is really strange to see this kind of gap between theory and practice. This trend is much stronger at a stage well past the undergraduate level where Gender Studies is offered only as one course among many (Sreenivas, 2015).

Over the years, the RCWS has developed in many new directions; these directions were not necessarily the result of careful planning but often the product of chance and the availability of funds. Despite this element of chance in the development of RCWS, it has retained its core commitment to feminist politics through its theoretical and action research as well as extension and teaching programmes [Krishnaraj (2001), quoted in Poonacha (2003)]. The status of Women's Studies at university is further highlighted by Poonacha (2003) as:

Entrenched in the university system, women's studies scholarship has given rise to hierarchies among scholars. These scholars face contradictory pulls. They are expected to produce high quality research, and at the same time are expected to bring about social change through activism and extension activities. The current expectations from women's studies centres and cells are not easy to fulfill in an environment that is bogged down with bureaucratic tangles and non-availability of funds. There is also an erosion of secular democratic forces within the university system. 
Therefore apart from fighting for survival against the onslaught of globalization and privatization of higher education, they are battling against conservative forces.

She has also critiqued the UGC Tenth Plan Profile where women's studies is relegated to extension activities of universities and had to compete for funds with Family Studies. Such institutional structures raise doubt over the possibilities of Gender Studies as an inclusive tool to development of the society.

UGC, in its $12^{\text {th }}$ Plan Guidelines $(2012-2017)$ for Development of Women's Studies in Indian Universities and Colleges, aims at Capacity Building of Higher Education. This Guideline's document identifies the following achievements till now:

1. Reworked principles for phasing WSCs and developed criteria for up-gradation.

2. Increased the number of WSCs to 159 so that at the end of the XI Plan, the Phase I Centres are 116, Phase II Centres 30, Phase III Centres 10 in number. Three Centres have been recognized as Advanced Centres.

3. Granted eligibility for NET and JRF to all postgraduate degree holders with the required minimum credits (16) in Women's Studies.

4. Increased the strength of faculty and added permanent positions in Central Universities.

5. WSC's faculty has been granted salaries recommended by the Sixth Pay Commission to give them parity with the rest of the faculty within universities.

6. Evolved sample courses for undergraduate and postgraduate programmes of study after an extensive review of the courses offered by the Centres.

Despite these achievements the Research Centres for Women's Studies (RCWS) have assumed a confused role as neither an entirely research institution nor as a fully academic course at University level. But it was a revolutionary measure in its own way. It was the first major break off from the usual, i.e., women as objects of study to now, women as the focus in researches.

UGC currently (in its $12^{\text {th }}$ Plan) has plans to develop Nodal Research Centres (Advanced Centres and Select phase III Centres on the basis of their proven strengths) which will act as inter-University resource centres for enhancing the quality of teaching and research in Women's Studies and provide sustained support especially to new Centres and new faculty (UGC $12^{\text {th }}$ Plan Guideline, P23). Therefore, Women's Studies have got a good volume of attention from UGC. But, as many claim, Women's Studies Centres (WSCs) have become NGOised following these guidelines with too limited scope within the institutional structures. The activities of these centres comprise of organizing workshops, trainings, implementation of scheme in partnership with NGOs. But these are not enough to make Women's Studies what it had sought to do.

\section{Pedagogical Challenges and Links to Social Institutions}

A Women's Studies or Gender Studies class room should help the learners raise their awareness about aspects of gender and its overlapping components like caste, class, religion, region, language and nationality with intersectionality as a very critical tool of developing the feminist perspective. Various feminist scholars have talked about different approaches for feministic pedagogies.

Many of the critical pedagogical tools used in Women's Studies are drawn from Sociology. As we know from Sociology, there are more linkages between social institutions and the modes of learning and engagement. Rege (2010) has mentioned about the 'relations of power' organized by the curriculum. She notes that the approaches to the curriculum have been discussed to some extent, but those related to the organization of college or university classroom as a physical and intellectual space has been relatively unaddressed.

Rege (2010) has further noted about the Phule-Ambedkarite pedagogy:

The "difference" of Phule-Ambedkarite pedagogical perspectives lies in a double articulation that conceives education then not only in terms of cultures of learning and teaching but also dissenting against that which is learnt and taught by dominant cultural practices. This entails constituting teachers and students as modern truth seekers and agents of social transformation who seek to become "a light unto themselves". The methods are those that seek to integrate the principles of prajna (critical understanding) with karuna (empathetic love) and samata (equality).

Rege (2010) has also suggested the significance of intersections of another critical pedagogy (African-American feminist pedagogies) that directly links with political commitment in "envisioning education as the practice of freedom and thus to challenge the assumed dichotomies of $\mathrm{mind} /$ body, public/private and reason/emotion'. As one views it, learning through such pedagogies should focus on solving the challenges that the structural inequalities pose. In this case, an assimilatory pedagogy needs to be elicited to structure the thinking of young minds so that they meet the challenges head-on and move beyond the structures that limit social progress. An assimilatory pedagogy focusing on praxis of Women's/ Gender Studies can close the gap between theory and practice. This needs to be tackled by delimiting of spaces within the university ecosystem. Such a praxis also needs to be implemented at school level learning and should not be restricted to Women's/ Gender Studies departments or WSCs only.

Another aspect that is of concern especially in a huge 
and diverse country like India is that of inclusiveness. Women's Studies though being about inclusive development and empowerment of women have found a limited in reach in visibilizing its agenda to the masses. Manjrekar (2003) has discussed how feminist engagements with the politics of knowledge have largely bypassed school education which continued to offer a 'narrow range of subject positions for girls and women, locating and even objectifying them as mere instrument in the narrative of national progresses'.

Also, many young men and women at technical universities, B-schools, journalism and media institutes, etc. have remained alien to Women's/Gender Studies. Also these fields still lack the perspectives of marginal identities and continue to operate in the same gender blind fashion. When the National Policy on Education came out in 1986, it viewed education as a premier instrument for promoting equality of status and opportunity between men and women and between groups divided by class, caste and other forms of historic oppression.

Irrespective of the guidelines of the National Policy on Education (NPE) of 1986 which emphasized the necessity of re-orienting education to promote a gender perspective, school education has remained marginal to knowledge-building within the women's movement and Women's Studies \{Manjrekar (2003) quoted in Sreenivas (2015)\}. Hence, Women's Studies in India can be viewed as an essential method to promote the national Educational Objectives (Pande, 2013).

Women's Studies can play a central role in empowering individual women and society at large. Today, sufficient research and interventions have been made to change the position of women at household and economic levels. Social structures primarily education can also be taken on board: by redesigning the education curriculum, developing gender aware pedagogies, restructuring syllabus, teachers' training \& (re)orientation, orientation of educational administrators and policy makers, and the goal would be easily achievable with diverse partners.

The emphasis on feminist perspective meant a realization of power relations inherent in current knowledge frameworks and practices in terms of who has access to that knowledge, how it was distilled and eventually how meaning was encoded \{Spender (1981), quoted in Pande (2013)\}. A meaningful involvement of sensitive individuals at all levels of decision making is needed. Though the decision making at local level currently involves women through a minimum of 30\% reservations in Panchayats and Municipal bodies, a gender aware professional also needs to be employed at such levels.

Women's movement which led to formation of Women's Studies right now needs to be replenished again. Also, Women's Studies as a discipline got only limited reach among most of the youngsters. It is the institutions of learning that can successfully bring about the notions of equality in societies. Breaking away from discriminatory institutions is not an easy process as these very institutions are fundamental to one's existence. Therefore, learners should be taught to stand on the ground against these institutions. They should also be motivated to develop their own methods to solve the problem. The learners of this discipline should be encouraged to develop new methodologies to address the problems with other institutions. It can be done with each centre allocating a particular project/area to each learner (or as groups) for solving an issue local to them. Government and/or Non-government machineries and development bodies can be allies to this crucial venture.

Gender studies practitioners should be placed as the advisors for the curriculum development of courses at school and university levels. In every social science research at Masters and Ph.D. level at least one Gender guide should be mandated to ensure gender sensitive approaches in these researches. They should be included at all levels of policy planning, designing and implementation.

\section{Conclusions}

To mainstream the gender perspective in other disciplines, courses imparting knowledge about gender analysis tools, gender budgeting, gender planning, gender and livelihood studies, gender and statistics, feminist research methods, etc. should be introduced at undergraduate and post-graduate levels. Simpson (1986) has referred to Women's Studies in these words:
"Women's Studies are more than one reference to a powerful woman, more than one course in a department about women, more than a woman's division in association, more than one panel at a conference, more than one article in a scholarly journal. It entails the full inclusion of Women's Studies material in all research, scholarship and teaching".

Women's Studies grew from the historical struggle for women's liberation and rights. Later, it was entrusted with the responsibility to prepare women for this purpose. Women's studies apart from providing a theoretical base for women's movements, has also brought a sense of balance in the social sciences which, by ignoring women, had presented a distorted view of social reality (Ganesh, 1985). This is from where a new form of women's movement is needed to tackle new challenges. Moreover, identities other than woman, who are pushed to the margins of development and growth, need to be made allies in the difficult process reaching equality for all. 


\section{REFERENCES}

[1] Anandhi, S., \& Swaminathan, P. (2006). Making it relevant: Mapping the meaning of Women's Studies in Tamil Nadu. Economic and Political Weekly, 41(42), 4444-4454.

[2] Ganesh, Kamala (1985). State of the Art in Women's Studies. Economic and Political Weekly. Vol. 20(16). $683+685+687-689$.

[3] Jain, Devaki. Rajput, Pam (2003). Narratives from the Women's Studies Family. Ed. New Delhi/Thousand Oaks/London: Sage Publications

[4] John, M.E. (2008). Women's Studies in India: A Reader. New Delhi: Penguin.

[5] Mazumdar, Vina. Sharma, Kumud (1979). Women's Studies: New Perceptions and the Challenges Economic and Political Weekly. Vol. 14(3). 113+115-120.

[6] Pande, Rekha (2013). Women's Studies: An Institutional Experience. Women's link, Vol. 19, No. 2.

[7] Patel, Vibhuti (2012). Newsletter. Indian Association for Women's Studies (IAWS). Volume II, No. 9
[8] Poonacha, Veena (2003). Women's Studies in Indian Universities: Current Concerns. Economic and Political Weekly. Vol. 38(26). 2653-2658

[9] Rege, S. (2010). Education as Trutiya Ratna: Towards Phule-Ambedkarite feminist pedagogic practice. Economic and Political Weekly, 45(44), 88-98.

[10] Sharma, Kumud (2002). Women's Studies and Higher Education: The Troubled Journey. Indian Journal of Gender Studies. Vol. 9(2). 209-219.

[11] Sharma, Kumud (2003). Institutionalising Feminist Agenda(s). Economic and Political Weekly. Vol. 38(43). 4564-4566

[12] Sreenivas, Deepa (2015). Between Politics and Discipline: Gender Studies in an Institutional Setting. Indian Journal of Gender Studies. 22(2). 265-281.

[13] Tambe, Anagha (2015). Newsletter. Indian Association for Women's Studies (IAWS). Volume III, No. 4

[14] UGC $12^{\text {th }}$ Plan Guidelines (2012-2017) for the Development of Women's Studies in Indian Universities and Colleges, New Delhi. 